\title{
REVIEW OF A BUTTERFLY FIELD GUIDE - 80 YEARS LATE
}

BERNIE GOLLOP, 2202 York Ave., Saskatoon, SK. S7J 1J1

The fascinating excerpts well on in this article are from what was probably the first field guide for North American butterflies: How to Know the Butterflies - A Manual of the Butterflies of the Eastern United States. It was written by John Henry and Anna Botsford Comstock, both professors at Cornell University, Ithaca, NY. The title page indicates that it was published by Appleton, New York, in 1917, but the copyright date on the next page suggests that the identical version may have appeared in 1904. (See also Cabbage Butterfly dates below.) I bought it for $\$ 17.75$ at A Book Hunter - Wayne Shaw's secondhand bookstore in Saskatoon. It was originally purchased from Hazen-Twiss which did business in Saskatoon from 1912 to 1977 . The signature at the front is something like D. (or S.) H. Birmia or Binnig.

It is a 311-page hardcover about the thickness of the Audubon butterfly guide and, otherwise, with the dimensions of the National Geographic bird guide. A 34-page introduction deals with "structure," "clothing," "metamorphoses," and "study of the life of butterflies." The latter discusses and illustrates breeding cages, collecting equipment and methods of preserving. Text for each species includes a paragraph on "adults," on "caterpillar" and on "food-plants," followed by general comments. Keys are presented for all species by groups. Forty-nine black-and-white sketches and excerpts from some 40 poems are scattered throughout.
This volume illustrates 123 species of adults in 38 plates, compared with 453 in 35 plates of Peterson's 1992 eastern butterfly guide. With some 150 species in each province, Manitoba's butterfliers would have found 84 of their butterflies in this book, Saskatchewan's 69 and Alberta's 57.

All species are illustrated in colour - "plates from life reproducing the insects in natural colours." The legends for each plate are printed on a facing sheet of tissue paper. The images appear to be good colour photos but on the sheets facing illustrations of larval and chrysalid stages is the statement "From photographs by Professor M.V. Slingerland, coloured by Mrs. Slingerland." While not stated anywhere, something similar must also apply to the adult plates.

For adult butterflies, about twothirds of the plates show from one to three species; the remainder have up to nine (skippers have $19 \mathrm{im}$ ages); either the whole butterfly or half of it is shown. Sometimes male and female are depicted, sometimes upper and lower surfaces. Seven plates illustrate "transformations" of seven species, always with larva and pupa, sometimes including egg and adult.

Nomenclature over 80 (or 93) years has evolved into a problem. The most frequent changes appear to be in the scientific genus name, the fewest in the scientific species name. Some of the more interesting 
common name changes include from Blue-eyed Grayling to Common Wood Nymph, Purple Disk to Bog Copper, Canadian Skipper to Common Branded Skipper and Mormon to Hobomok Skipper. The most difficult to interpret was "Tessellate Skipper" wherein "Hesperia tesselatus" has no relationship to Common Checkered Skipper which it looks like from the illustration.

The general comments make for much more entertaining reading than the above. Here are some excerpts. (Names are given as they were then, followed by current common names, if different, in parentheses, from the North American Butterfly Association's 1995 checklist.)

\section{Tiger Swallow-tail (Eastern and} Canadian Tiger Swallowtails). And as if to demonstrate that it is truly at home wherever it may be and that it has no race or colour prejudice, it has in the South wives that are black. It is a brave flyer and lifts itself easily over houses and trees. It is especially a habitant of the latter; from our upper windows we have watched it fluttering about among the tip-top branches quite as much at home as on the lilac bushes or on the peonies of the lawn. It has a catholic taste in the matter of odour, and is equally devoted to fragrant flowers and to waste matter by no means fragrant. Its special weakness is tobacco smoke. When fishing in the Adirondacks it was one of the daily diversions of the senior author, while resting to smoke a cigar, to watch the tiger swallow-tails come one by one out of the wilderness and flutter about him with every sign of enjoyment; if he held quite still, they would settle comfortably on his forehead or shoulders a little to the leeward so as to enjoy to the utmost the luxury of a second-hand smoke. (p. 53)
Cabbage Butterfly (Cabbage White). If butterflies were in the habit of forming protective associations, some thirty years ago we would have heard of cabbage leaf petitions signed by various native Americans who were being supplanted by foreigners "plentiful and cheap." America had white cabbage butterflies of her own with most interesting and intricate histories; they were conservative in habits and did not appear in vulgar hordes, but took their toll quietly from all our cruciferous plants of the garden and especially from the cabbage. In 1860 the European cabbage butterfly was introduced at Quebec, and in 1868 it gained footing in New York. From these points has spread this important foreigner and, by appearing earlier in the season and having more broods a year, it has starved and driven out of American gardens the native cabbage butterflies; these have fled before the invader to the wilderness and there lead a precarious existence on wild Cruciferae. (p. 79)

Those old days when the balancing of a yellow butterfly over a thistle bloom was spiritual food and lodging for a whole afternoon. Lowell (p. 87)

\section{Roadside Butterfly or Clouded} Sulphur. It hovers over flowers of the field, especially loving the yellow blooms; but more than all this, it loves to hold banquets around the mud-puddles in the road. Almost any time in August when driving along a country highway we may see at a distance in front of us a shining yellow blotch which scatters on our approach into a hundred yellow butterfly fragments; and if we afterward examine the spot closely we can see the mud perforated with "pinholes" where these thirsty creatures have thrust their long tongues. (p. 93) 
Great Spangled Fritillary. When we were children a familiar sight to us on our journeys to and from school were certain large round-winged tawny butterflies settling themselves as best they could on the thistle blossoms. When finally engaged in exhausting the sweets at this roadside restaurant, their wings were lifted and closed and we saw on their lower sides what we called "butterfly money." This currency was of various denominations, and near the edges were what we called "dollars" broken in halves and set in a row, a fact which puzzled us until we discovered the lost halves set in a row on the opposite wing; a charming lesson in short division this. (p. 115)

\section{Silver-spot Fritillary (Aphrodite} Fritillary). When we made our childish observations on the butterflies that had adopted a free silver coinage we often crept up carefully and seized one of them by his closed wings and counted his "dollars" for him. (p. 117)

\section{Mountain Silver-spot (Atlantis} Fritillary). If our childish fancy about butterfly money were true this fritillary would carry on its wings the currency of the Dominion of Canada, for inere is its home and it only visits our mountains and highlands. (pp. 118119)

Meadow Fritillary. This little fritillary has put no money in its purse; there is not a single silver spot, angular or round, to be found on the lower side of its wings ... It has some queer habits. Many of the butterflies of the first brood appearing early in May evidently feel that they have the whole summer before them and are likely to neglect the important transaction of egg-laying for several weeks. (pp. 120-121)
Silver-bordered Fritillary. When in our childish ignorance we regarded a small butterfly as not yet fully grown, we often found on thistle blossoms in the pasture certain small butterflies that carry "money" under their wings and we thought them too young to be trusted with so much silver. (p. 122)

Pearly Eye (Southern and Northern Pearlyeyes). The pearly eye, clad in fawn-coloured satin ornamented with oblong medallions of seal-brown velvet, is, from the point of view of the modiste, the most beautiful of our American satyrs ... in the north as far as Manitoba and Nova Scotia. (p. 190)

Eyed Brown. For many years, and also in many books, the species is called eurydice; but Orpheus has evidently found another Eurydice among the butterflies, a daughter of the sunlight instead of the shades, and this one disports itself under the name of canthus. (pp. 192-193)

Little Wood-Satyr. This lively butterfly is as jolly as a little wood-satyr ought to be. It has a skipping, dancing, care-free flight, never rising far above the ground. (p. 198)

Monarch. The male monarch is the dandy among butterflies par excellence. $\mathrm{He}$ is not only trig in figure and gorgeous in colour, but on each hind wing he carries a black sachet bag for the allurement of his lady-love. And she is as brilliant as he, but lacks the perfume pockets. "I am monarch of all I survey"-is exemplified in the confident, serene flight of this butterfly ... Nor is the monarch satisfied with these journeys to the north and south; it is the strongest flyer of all the butterflies and does not hesitate to try its fortune over the seas, and has been found flying five hundred miles from shore. Either by 
flight or as stowaways in vessels it has pressed eastward to Europe and westward to the isles of the Pacific. (pp. 205-06)

Acadian Hair-streak. This butterfly must have been expelled from Acadia with Evangeline, as there is no record of its having been found as far north as Acadia since it was discovered and named. (p. 225)

Banded Hair-streak. From the West comes the report that in the spring it shows a liking for the odoriferous skunk-cabbage, a plant which seems to have more friends among insects than among folks. (p. 227)

Hoary Elfin. It is the laziest of all the hair-streaks and loves to loaf around shrubs in open places, and even haunts the roadsides. The caterpillar is a little rascal that burrows in and devours the fruit of the wild plum. ( $p$. 233)

American Copper. We have always been very sorry for those unfortunate people who have never had a pair of these beautiful midgets as tenants of their lawn. For years we have had at least one pair on ours to fly at us when we came out and by making desperate dashes at our heads try to drive us off of what they consider their preserves. They evidently base their claims on the presence of sorrel, which once we would have deemed a disgrace to any lawn. But lawns, like children, were evidently meant to educate their possessors; and while we began with strenuous effort to have only clover and grass on ours, indefatigable Nature planted all things there as soon as our backs were turned. After a time we grew in grace and came to love the dandelions and dock, orchard grass, and white daisies; and more than all do we appreciate the rosy bloom which sorrel lends to our possessions, especially because of it, a pair of American coppers live with us ... Once we saw them attack a tiger swallow-tail and drive him off the premises; and once we saw them chase a huge bulldog with the same confidence and aplomb. (pp. 242243)

Silvery Blue. There are several things in this world that it were better to know nothing about, such as a perfect passage of music or a bit of exquisite colour. Both were meant to appeal to the soul through the senses, and knowledge about them is superfluous and a distracting factor, Therefore we feel a certain satisfaction in not being able to give any facts about life history of the silvery blue. All that we know is that it bears on its wings a blue found nowhere else in the world except in the pearly spectrum of the sea-shell ... (p. 246)

Tailed Blue (Eastern Tailed-Blue). The tailed blue is in possession of the greater part of America from the Atlantic to the Pacific, from the Isthmus to the British dominions. ( $p$. 255)

Bubble, bubble flows the stream Like a song heard in a dream. A white-faced hornet hurtles by, Lags a turquoise butterfly One intent on prey and treasure, One afloat on tides of pleasure! Maurice Thompson (p. 255)

They don't write field guides like that anymore! 